\title{
Carbon storage in agroforestry: an estimate for sub-Saharan Africa
}

\author{
J. D. Unruh ", R. A. Houghton, P. A. Lefebvre \\ The Woods Hole Research Center, PO Box 296, Woods Hole, Massachusetts 02543, USA
}

\begin{abstract}
Massive reforestation has been proposed as one means for stabilizing the concentration of carbon dioxide in the atmosphere, but the proposal seems academic in the face of current rates of deforestation in the tropics and the growing need for additional agricultural land. Agroforestry offers a compromise solution because it increases the storage of carbon on land and, at the same time, may enhance agricultural production rather than compete with it. Although the storage of carbon per unit. area is generally less for agroforestry than for forests or tree plantations, the area suitable for agroforestry, worldwide, is large. In this study, we estimated the amount of carbon stored in different agroforestry systems in sub-Saharan Africa and the potential storage possible, region-wide, if agroforestry were to be implemented throughout. The potential distribution of different agroforestry systems was determined from a comparison of current practices of agroforestry with current land use. Land use was determined from a combination of satellite data and ground studies. A total of about $1550 \times 10^{5}$ ha were classified as suitable for some type of agroforestry. Although certain types of agroforestry accumulate much more carbon than others, practical implementation of agroforestry must consider existing landuse practices. Those types of agroforestry that included fuelwood production were most consistent with current land use and thus had the greatest potential to accumulate carbon. Tulal potential accumulation of carbon in aboveground woody biomass in agroforestry ecosystems throughout sub-Saharan Africa was estimated to be 6,13 , or $23 \mathrm{Pg} \mathrm{C}$, depending on the density of trees used in the various systems. Including belowground biomass and the potential for soils to accumulate carbon under agroforestry raised these estimates to between 8 and $54 \mathrm{Pg} \mathrm{C}$. Accumulation of that much carbon would offset global emissions of carbon from fossil fuels for only 1.7 to $9 \mathrm{yr}$, but would offset African emissions for 20 to 125 yr The secondary effects of agroforestry in reducing rates of deforestation and, hence, emissions of carbon, may be more important than the primary effect of sequestering carbon.
\end{abstract}

\section{INTRODUCTION}

Increasing concentrations of greenhouse gases in the earth's atmosphere are expected to warm the earth and cause other, less easily predicted, changes in climate. The warming will continue until sometime after atmospheric concentrations of the major greenhouse gases are stabilized. Carbon dioxide $\left(\mathrm{CO}_{2}\right)$ is the most important of the greenhouse gases released as a result of human activities. It is expected to account for about $60 \%$ of the warming over the next century according to

\footnotetext{
- Present address: Department of Geography and Regional Development, University of Arizona, Tucson, Arizona 85721, USA
}

a recent assessment by the Intergovernmental Panel on Climatic Change (IPCC) (Houghton et al. 1990). Stabilization of $\mathrm{CO}_{2}$ concentrations in the atmosphere will require large reductions in the use of fossil fuels and in rates of deforestation. But while reductions in emissions of carbon will enable the concentration of $\mathrm{CO}_{2}$ in the atmosphere to come to a new equilibrium with the partial pressure of $\mathrm{CO}_{2}$ in the oceans, the time required for this equilibration may be hundreds of years. Reforestation, on the other hand, defined here as an increase in woody biomass, could remove significant amounts of $\mathrm{CO}_{2}$ from the atmosphere over decades.

A major limit to reforestation is area. On the order of 900 to $1200 \times 10^{6}$ ha of land would have to be refor- 
ested to accumulate all of the carbon emitted annually from worldwide combustion of fossil fuels (Marland 1988, Sedjo 1988, Woodwell 1989, Houghton 1990); and, even then, the annual accumulation in new forests would balance emissions only as long as the forests were maturing After 25 to $50 \mathrm{yr}$ or so, the annual accumulation on land would decline to zero, and the emissions would again, as now, accumulate in the atmosphere

In the tropics, degraded areas suitable for reforestation are estimated to range between 500 and $900 \times 10^{6}$ ha (Grainger 1988, Houghton 1990), the higher estimate including lands currently under fallow and hence already holding some amount of carbon in woody biomass. These lands are defined as suitable because they once supported forests, and presumably could do so again, and because they are no longer used intensively for agricultural purposes. Most of the lands were farmed in the past but have since lost their fertility and been abandoned. Because forests are being cut down largely to increase the area in agriculture, it is unlikely that productive agricultural lands will be reforested to accumulate carbon. On the other hand, the accumulation of carbon in woody biomass need not compete with agricultural production. Almost $2000 \times 10^{6}$ ha of land currently in crops and pastures in the tropics is suitable for accumulating carbon with little or no loss of agricultural productivity. The practice is called agroforestry.

Agroforestry has the potential to sequester significant amounts of carbon for 2 reasons. First, the area currently in crops and pastoral systems is large. Second, although the density of carbon storage is low in comparison with forests, the woody biomass of agroforestry systems could provide a source of local fuel This fuel would reduce pressure on the remaining forests in the area and, at the same time, provide a substitute for fossil fuel. These effects are important because the most effective way to use land for stabilization of atmospheric carbon is not through reforestation but through the substitution of wood fuel for fossil fuel (Houghton 1990, Hall et al. 1991). As much as $150 \mathrm{Pg} \mathrm{C}$ ( $1 \mathrm{Pg}=1 \times 10^{9}$ metric tonnes $\left.=1 \times 10^{15} \mathrm{~g}\right)$ might be accumulated in the tropics if $865 \times 10^{6}$ ha were reforested (Houghton 1990), but, as noted above, the rate of accumulation would fall to zero as the forests matured. Forests would continue to hold the carbon accumulated, but they would accumulate no additional carbon after that time. In contrast to the temporary effect of reforestation, the sustainable use of wood fuels provides a solution that could last indefinitely. Under sustainable use, emissions of carbon from burning this year's fuel are balanced by accumulations of carbon in the growth of next year's fuel: the net flux is zero. In 1990 emissions of carbon from worldwide combustion of fos- sil fuel were about 6 PgC (Houghton et al. 1992). Fossil fuels are non-renewable, carbon-emitting fuels; wood, if managed sustainably, is a renewable, zero-carbon fuel.

However, despite the large area devoted to agriculture worldwide, and despite the apparent potential for agroforestry to sequester carbon, the recent proliferation of agroforestry studies includes almost no consideration of either carbon or biomass. The lack of biomass data, coupled with the diversity of agroforestry types (i.e. the wide variation in functional types, species, tree densities, temporal and spatial arrangement of components, management practices, etc.), means that a straightforward estimation of potential carbon storage is not possible.

The purpose of the analysis described here is (1) to present a methodology for estimating the aboveground biomass in different types of agroforestry, and (2) to estimate the total amount of carbon that could be stored in agroforestry over the entire sub-continent of sub-Saharan Africa. Following a brief overview of the approach, the paper describes the methods developed for this analysis. The results are compared with other studies and, finally, the secondary effects of agroforestry for the potential storage of carbon are discussed.

\section{APPROACH}

The approach combined site-specific information from case studies of agroforestry with a land-use database for sub-Saharan Africa to estimate the total amount of aboveground biomass that might be accumulated if agroforestry were to be practiced on lands presently suitable. Suitable lands included agricultural lands and degraded lands. They did not include forests, grasslands, or deserts unless those lands were grazed. Sitespecific case studies of agroforestry were obtained from The International Council for Research in Agroforestry (ICRAF)'s database on agroforestry (Nair 1989a) and from other sources in the published literature. The advantage of using this information is that it contained descriptions of existing, functioning examples of agroforestry as presently practiced. The examples included the many forms of agroforestry that result from the interplay of climatic and land-use options in various regions of Africa. They already embody the many biophysical and human variables involved in functioning agroforestry systems. In this sense, our analysis was not hypothetical or theoretical but, rather, based on agroforestry as currently practiced.

Over 170 descriptions were used to categorize the types of agroforestry actually practiced. These descriptions encompassed a wide variability in tree density, 
species, size, temporal and spatial patterning, and management practices. The descriptions were grouped into 5 different types of agroforestry (see Table 1). Silvopastoral agroforestry was further divided into 3 sub-types due to large differences (largely related to precipitation) in tree biomass for fodder-producing trees in pastoral zones. Most of these major types of agroforestry are not practiced alone, however, but in combination with other types. Thus, a total of 21 different agroforestry types were considered (see Table 2). In addition, within each type of agroforestry, a high, medium, and low biomass value was estimated, to encompass the variability resulting from the number of trees per hectare.

These 21 types of agroforestry were distributed over sub-Saharan Africa on the basis of 2 kinds of information. First, the geographic regions and precipitation regimes for each type of agroforestry, obtained from the ICRAF study and other agroforestry studies, gave a general description of where different types are found. Second, a map of current land use in sub-Saharan Africa was used to place, more specifically, different types of agroforestry within current uses of land. The derivation of both maps is described in the next section.

The type of agroforestry chosen as appropriate for a given land use involved a set of rules. For example, fodder-producing trees were assumed appropriate for pastoralism; shelterbelt agroforestry was appropriate for rainfed crop systems; fruit and fuelwood agroforestry was most appropriate for shifting cultivation systems; and so on. When more than one type of agroforestry was appropriate for an existing use of land, 2 types were assumed to be practiced together. We arbitrarily limited the number of coexisting types to 2 . The decisions defined a third GIS (geographic information system) layer which identified areas for implementation of specific agroforestry types. These areas were then multiplied by the per-hectare estimates of woody biomass for each agroforestry type to give estimates of biomass potentially accumulated in all types. The estimate is not of current accumulation because agroforestry does not entirely cover these areas at present. The potential storage is what would occur if agroforestry were to fill the suitable areas. The estimates do not include carbon sequestered through the secondary effects of agroforestry. These effects are discussed briefly toward the end of the paper.

Throughout the paper, we refer to the increment in aboveground woody biomass associated with different types of agroforestry. We assume that the biomass of non-woody vegetation is not changed as a result of agroforestry, and thus we ignore non-woody vegetation. The potential increments in belowground biomass and soil carbon are considered at the end of the paper Until then, the units used throughout refer to aboveground woody biomass (dry weight). For considerations of carbon, in a final section, we assume carbon to be $50 \%$ of biomass.

\section{METHODOLOGY}

Determination of biomass. In assessing the various options for estimating woody biomass of agroforestry systems, it became readily apparent that no single method would adequately estimate biomass for all systems. Because of large differences among agroforestry systems in tree size and wood density, environmental conditions, temporal and spatial structure, function, and management practices, calculation of per-hectare tree biomass was different for each type of agroforestry. What follows is a description of the calculation of biomass for the different systems included in this study

Silvopastoral agroforestry systems: The utilization of fodder-producing trees as animal feed sources has been known in livestock producing areas for centuries. Especially important in arid and semi-arid grazing lands, silvopastoral agroforestry systems are being increasingly practiced and studied (Torres 1989 and references therein). These systems usually comprise trees and/or shrubs in extensive browsing or grazing systems, where the trees act as protein-rich supplemental feed sources, or primary feed sources in certain times of the year or during drought (Boudet \& Toutain 1980, Torres 1983, Coppock et al. 1986, Poschen 1986, Phillips et al. 1989, Barrow 1991).

A review of the relevant literature reveals that variation in per-hectare biomass for silvopastoral systems is primarily due to variation in precipitation and the number of trees per hectare (Bille 1985, Martin 1985. Almanza \& Moya 1986). The approach used here for estimating biomass considered both of these variables by delineating precipitation zones, and by defining 3 values for number of trees per hectare based on the range of trees per hectare observed in silvopastoral systems. The precipitation zones were defined following Boudet \& Toutain (1980). Estimates of tree biomass were obtained from Bille (1985), Martin (1985), and Almanza \& Moya (1986). The average fodder-producing tree for the $100-400 \mathrm{~mm}$ zone contains $3.6 \mathrm{~kg}$ biomass, for the $400-800 \mathrm{~mm}$ zone, $3.5 \mathrm{~kg}$, and for precipitation $>800 \mathrm{~mm}, 97 \mathrm{~kg}$. These values multiplied by values for numbers of trees per hectare $(50,100$, and 200) gave 3 estimates for each of the 3 precipitation zones, or a total of 9 estimates of per-hectare biomass for the silvopastoral agroforestry system (Table 1).

Fruit tree agroforestry: There are many examples of agroforestry systems in the tropics that involve large 
Table 1 Individual tree weight, number of trees per hectare, and average biomass for different agroforestry types

\begin{tabular}{|c|c|c|c|}
\hline $\begin{array}{l}\text { Agroforestry } \\
\text { type }\end{array}$ & $\begin{array}{l}\text { Tree welght } \\
(\mathrm{kg} \text { tree }\end{array}$ & $\begin{array}{l}\text { No. of } \\
\text { trees ha-1 }\end{array}$ & $\begin{array}{l}\text { Biomass } \\
\left(\mathrm{kg} \mathrm{ha}^{-1}\right)\end{array}$ \\
\hline \multicolumn{4}{|c|}{ (1) Silvopastoral } \\
\hline \multirow[t]{3}{*}{ (a) $0-400 \mathrm{~mm}$} & 3.6 & 50 & 180 \\
\hline & & 100 & 360 \\
\hline & & 200 & 720 \\
\hline \multirow[t]{3}{*}{ (b) $400-800 \mathrm{~mm}$} & 3.5 & 50 & 175 \\
\hline & & 100 & 350 \\
\hline & & 200 & 700 \\
\hline \multirow[t]{3}{*}{ (c) $>800 \mathrm{~mm}$} & 97 & 50 & 4850 \\
\hline & & 100 & 9700 \\
\hline & & 200 & 19400 \\
\hline \multirow[t]{3}{*}{ (2) Fruit tree } & 50 & 60 & 3000 \\
\hline & & 150 & 7500 \\
\hline & & 300 & 15000 \\
\hline \multirow[t]{3}{*}{ (3) Fuelwood } & 77 & 200 & 15400 \\
\hline & & 500 & 38500 \\
\hline & & 1000 & 77000 \\
\hline (4) Shelterbelts & 110 & 59 & 6490 \\
\hline \multirow[t]{3}{*}{ (5) Timber trees ${ }^{a}$} & 3250 & 40 & 130000 \\
\hline & 2000 & 120 & 240000 \\
\hline & 1350 & 200 & 270000 \\
\hline
\end{tabular}

numbers of fruit trees (Nair 1985). While fruit trees have a number of functions within various production systems, their primary purpose is to produce fruit for human consumption. As such their role in the production system is both in the direct contribution of foodstuffs and in income generation through the marketing of produce. Fruit tree agroforestry is very suitable to the smallholder farming systems of the tropics and other thickly populated regions of the world (Nair 1985).

In this study, estimation of biomass in fruit tree agro. forestry systems was based on calculation of the average biomass $(Y$ ) for a fruit tree. The following equation was used (Brown et al. 1989):

$$
Y=\exp \left\{-2.4090+0.9522 \ln \left(D^{2} H S\right)\right\}
$$

where $D$ is diameter at breast height $(\mathrm{cm})_{;} H$ is tree height ( $\mathrm{m}$ ); and $S$ is wood density $\left(0.57 \mathrm{t} \mathrm{m}^{-3}=\mathrm{g} \mathrm{cm}^{-3}\right)$. Wood density was calculated as the average of 5 species of tropical fruit trees commonly used in Africa (species from ICRAF agroforestry database - Africa; wood densities from FAO/UNEP 1981). A tree with a diameter of $15 \mathrm{~cm}$ and a height of $6 \mathrm{~m}$ was selected as average based on average fruit tree sizes from the agroforestry literature. The equation yielded an average biomass for fruit trees of about $50 \mathrm{~kg}$ tree $^{-1}$.

A range of numbers of fruit trees per hectare was obtained from a review of the agroforestry literature (Nair 1985, Fernandes et al. 1984, Michon et al. 1986, Denevan \& Padoch 1987, Toky et al. 1989, Allen 1990). Three values representing this range $(60,150,300)$ were used to derive the estimates of biomass per hectare given in Table 1.

Fuelwood agroforestry: Most Africans are almost wholly dependent on fuelwood for their energy needs and will most likely be so for decades to come (French 1978). At the same time, however, deforestation in Africa is proceeding rapidly. The potential of fuelwood agroforestry to help satisfy wood demand in Africa is great, primarily because of the enormity of the areas that could be planted (Anderson \& Fishwick 1984, Houghton et al. 1993). However, the trees providing fuel need not occur in forests or plantations, but can exist as free-standing trees in and around buildings, gardens, and fields (Anderson \& Fishwick 1984).

Estimation of biomass for fuelwood agroforestry was more straightforward than for other types of agroforestry because fuelwood agroforestry has received considerable technical attention. For this analysis, biomass was estimated by averaging a number of examples from the literature. These examples included both biomass per tree and number of trees per hectare (Anderson \& Fishwick 1984, Maghembe et al. 1986, Shankarnarayan et al. 1987, Millington \& Townsend 1989). Average biomass for fuelwood trees was estimated at $77 \mathrm{~kg}$ tree ${ }^{-1}$, and the range of trees $\mathrm{ha}^{-1}$ was 200,500 , and 1000 for low, medium, and high densities (Table 1). Because the trees are continually lopped for fuel and, thus, kept small, the normal inverse relationship between tree density and average tree biomass seems not to hold. Apparently individual trees do not interfere with each other, even at the higher densities. Because the trees are lopped (harvested) continually, aboveground woody biomass does not vary through time as it would if the trees were clearcut on a rotational basis. Thus, the increment in woody biomass associated with fuelwood agroforestry is equal to the standing woody biomass, and not to the average biomass over the harvest cycle.

Timber agroforestry: A number of agroforestry systems in Africa, most notably the widespread taungya system, contain timber trees. While these systems are different from timber plantations in spatial and temporal patterns, and in crop and livestock associations, the biomass of timber trees in agroforestry systems was assumed to be similar to that of plantations. Thus, data from plantations (FAO/UNEP 1981) were used to 
Fig. 1. Number of trees and voltropical plantations (FAO/UNEP 1981). The curve is a polynomial regression of stemwood as a function of number of trees umes of stemwood for mature

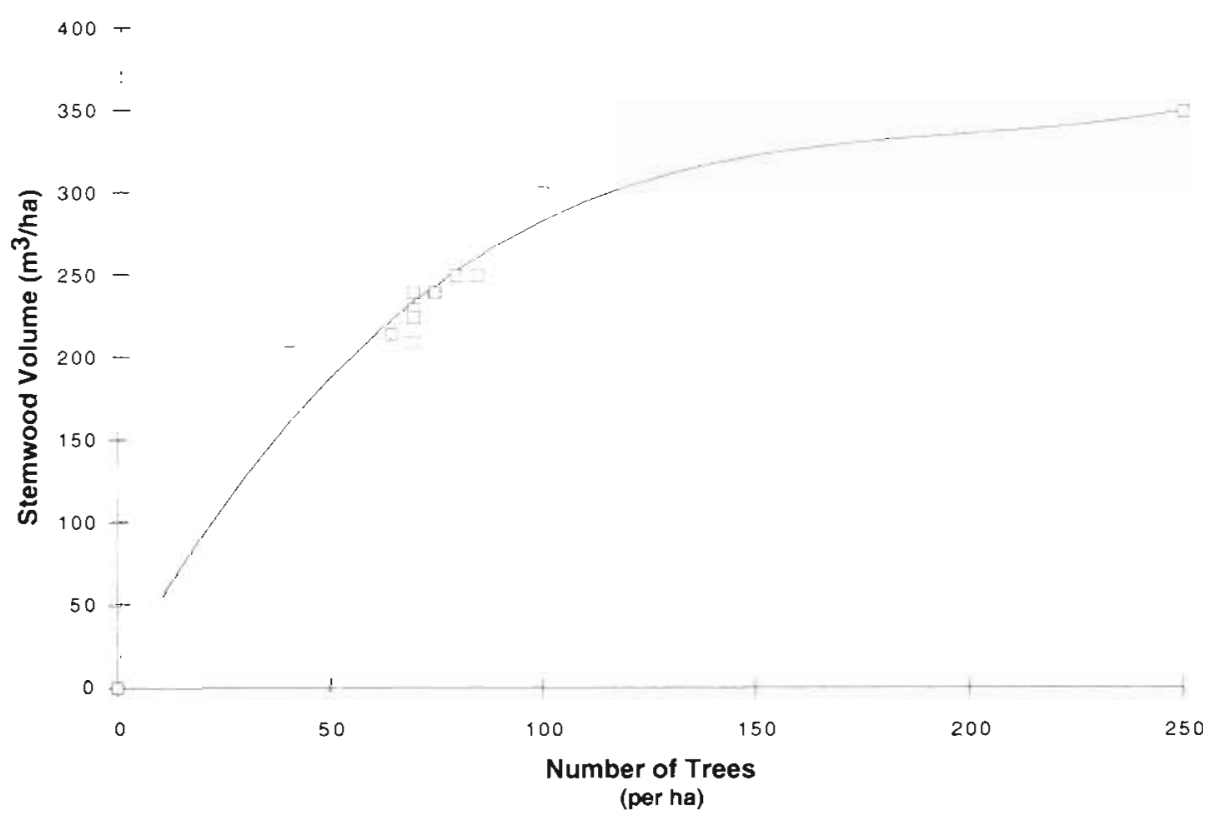

define the relationship between number of trees and stemwood volume (Fig. 1). The 11 points in Fig. 1 include 9 species commonly planted in tropical Africa. Eight of the species are planted in lowland humid tropical areas (mean annual rainfall > $1500 \mathrm{~mm}$ ); one species (from Mexico) is planted at high elevations (above $1000 \mathrm{~m}$, mean annual rainfall $>1000 \mathrm{~mm}$ ). Stemwood volume $\left(V=\mathrm{m}^{3} \mathrm{ha}^{-1}\right)$ was converted to total biomass according to the following equation:

$$
\text { Biomass }\left(\mathrm{t} \mathrm{h}^{-1}\right)=V \times S \times E
$$

where $S$ is wood density $\left(0.57 \mathrm{t} \mathrm{m}^{-3}\right.$; Brown \& Lugo 1984); and $E$ is the ratio of total aboveground biomass $\mathrm{ha}^{-1}$ to stemwood biomass $\mathrm{ha}^{-1}$. For plantations older than $30 \mathrm{yr}$, this ratio was estimated to be 1.4 (Brown et al. 1986).

We selected 40,120, and 200 trees ha ${ }^{-1}$ from the literature to represent the range of trees $\mathrm{ha}^{-1}$ observed in taungya agroforestry examples. These densities gave biomass estimates of 130,240 , and $270 \mathrm{t} \mathrm{ha}^{-1}$, intermediate between the minimum (111 $\left.\mathrm{t} \mathrm{ha}^{-1}\right)$ and maximum ( $518 \mathrm{tha}^{-1}$ ) estimates of biomass for tropical plantations greater than 30 yr of age (Brown et al. 1986). Most plantations in the tropics are younger than $30 \mathrm{yr}$ and contain less biomass than determined here, but the values calculated here were chosen to represent potential biomass rather than current biomass. They are values for mature plantations, ready for harvest. Hence, the trees are considerably larger than the trees of other agroforestry systems, where lopping, coppicing, or other activities often keep the trees small.

Shelterbelt agroforestry: Shelterbelts, or windbreaks, in agroforestry can have numerous functions in addition to preventing wind erosion. Depending on the species and the spacing, trees in shelterbelts can increase soil nitrogen and produce fruit, fodder, fiber, and fuelwood (Harrison 1987). Harrison (1987) cites studies showing that windbreaks can increase crop yields by 18 to $23 \%$, even allowing for the 12 to $15 \mathrm{~m}$ in every $100 \mathrm{~m}$ taken up by the trees and their deep shade.

Biomass estimation for shelterbelt agroforestry in this study was based on a single example, because very little else was available. The example used, however - of the Majjia Valley in Central Niger - is perhaps the best agronomic study to date of windbreaks in the Sahel (Van Denbeldt 1990). Using data from Leach \& Mearns (1988) on tree volume $\left(110 \mathrm{~m}^{3} \mathrm{~km}^{-1}\right.$ of shelterbelt), length of shelterbelt ha ${ }^{-1}\left(117 \mathrm{~m} \mathrm{ha}^{-1}\right)$, and spacing (trees planted in double rows with a spacing of $4 \times 4 \mathrm{~m}$ ), the average biomass of shelterbelts was calculated as 59 trees ha $\mathrm{a}^{-1}$ or $12.9 \mathrm{~m}^{3} \mathrm{ha}^{-1}$. Converting volume to biomass $(\times 0.57)$ gave $6490 \mathrm{~kg} \mathrm{ha}^{-1}$. Because only one example was obtained, high, medium, and low estimates were the same for this agroforestry type.

Combinations: While many agroforestry systems can be classified as one of the major types mentioned above, other systems are combinations of these different types. The remainder of the agroforestry types in this study were made up of combinations of the core types described above. These combinations were made up of only 2 types each, thus only approximately representing observed conditions. Biomass was estimated for these combinations by averaging low estimates for one system with low estimates for another, medium with medium, and high with high. The combinations are shown in Table 2 . 


\section{Precipitation}

\begin{tabular}{l}
$10 \mathrm{~cm}$ \\
Landcover \\
Desert \\
Grass/Shrub, <10\% woody \\
Sudan savanna \\
Grassland/Sudanian woodland \\
Salt desert \\
Forest \\
Edaphic grass/Semi-aquatic veg. \\
Pasture/Veld/Agricultural \\
Sudanian woodland \\
Shrubland/Bushland/Rainfed agric. \\
Wooded/Bushed grassland \\
Mosaic forest/Secondary grassland \\
Moist miombo woodland \\
Miombo woodland \\
Dwarf/Sparse shrubland \\
Plantation/Disturbed forest/Agricultural \\
Secondary/Degraded forest \\
Montane vegetation \\
Humid lowland tropical forest \\
$>75 \%$ cultivated \\
Fynbos shrubland \\
Dune fynbos \\
Proteoid fynbos \\
Very moist miombo \\
Shrubland/Mesotrophic fynbos \\
$60-80 \%$ eroded/degraded \\
$40-60 \%$ eroded/degraded \\
Cult. with some relicts mont. forest \\
Upland dry forest \\
Lake/Aquatic vegetation \\
Hi-elev. scattered Woodl./Forest \\
Forest, various types \\
Savanna/Wooded steppe/Rainf, ag. \\
\hline
\end{tabular}

\section{Regional precipitation zones}

West Arid
Central Arid
East Arid
South Arid
West Semi-arid
Central Semi-arid
East Semi-arid
South Semi-arid

\section{Potential agroforestry type}

Pastoral
Fruit
Fuelwood
Timber
Shelterbelt
Pastoral/Fruit
Pastoral/Fuelwood

Fig. 2. Layers in the GIS used to assign different types of agroforestry to the appropriate location. (a) Mean annual precipitation; (b) regional precipitation zones; (c) current land cover; (d) type of agroforestry compatible with current land use
Development of GIS layers. Precipitation, political regions, current land use and case studies were mapped on a GIS to identify areas suitable for specific types of agroforestry. Precipitation was obtained from monthly global maps of corrected total precipitation (Legates \& Willmott 1990). Individual months of precipitation were summed to produce a map of total annual precipitation in $10 \mathrm{~cm}$ increments (Fig. 2a). The precipitation map was then further simplified into 4 moisture regimes based on Nair (1989b): arid $(<500 \mathrm{~mm})$, semi-arid $(500-1000 \mathrm{~mm})$, subhumid $(1000-1300 \mathrm{~mm})$, and humid (>1300 mm). Political boundaries defined 4 geographic regions of Africa (West, East, Central, and Southern Africa) that coincided with ICRAF agroforestry cases (Fig. 2a). This 4 region map was combined with the map of 4 moisture regimes to produce a 16 -class map of regional precipitation zones (Fig. 2b). For most of these regions, descriptive data on prevalent agroforestry types (ICRAF) were of greater detail than the simple 16-class map, and we used a map of current land use/land cover to help decide which type of agroforestry was appropriate in specific locations.

A map of present-day land use/land cover with 33 classes (Fig. 2c) was produced from a combination of satellite data and ground studies (Houghton et al. 1993). The satellite data were weekly, $15 \mathrm{~km}$-resolution, Global Vegetation Index (GVI) data obtained from the National Oceanic and Atmospheric Administration (NOAA). The GVI data are calculated at NOAA from the Normalized Difference Vegetation index (NDVI), which is the difference between a visible and an infrared band, normalized by their sum. Dense vegetation cover results in high values of NDVI; areas of bare ground, ice and snow, water, or clouds give low values. NDVI is correlated with land cover, phenology, and net primary productivity over broad geographic areas (Goward et al. 1985, Justice et al. 1985, Tucker et al. 1985), but the index has also been shown to have a number of limitations (Goward et al. 1990, 1991, in press) 
a

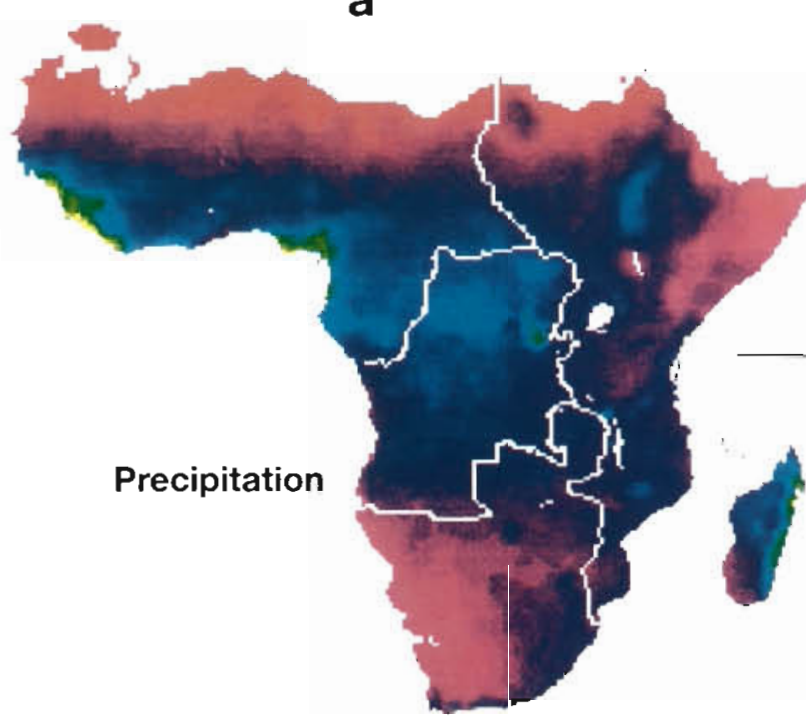

C

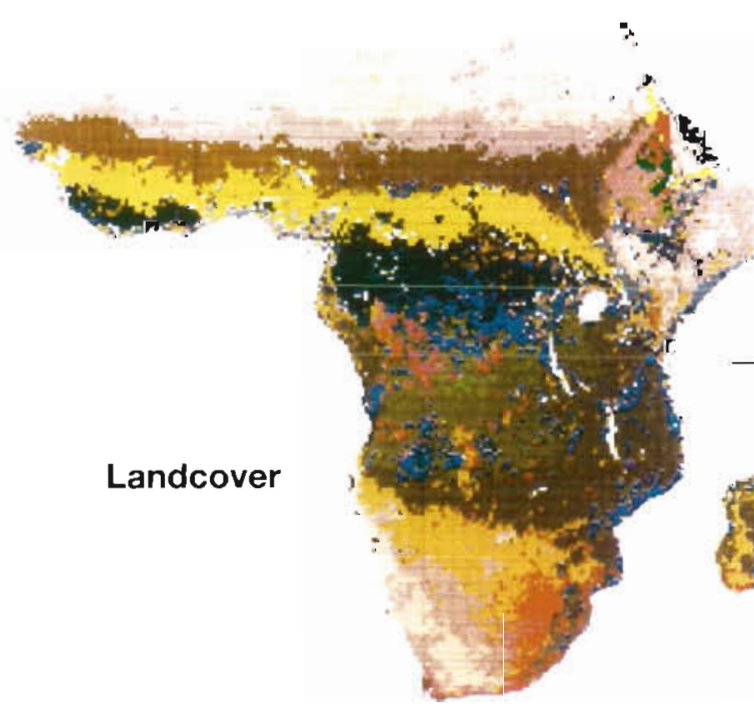

Three years (1986 to 1988) of recent GVI data were used to reduce the effects of interannual variability and spatial heterogeneity of climate that are especially problematic in Africa. Weekly GVI data were aggregated into months, taking maximum values from the component weeks, thereby reducing the effects of cloud cover. Monthly data were averaged for the 3 years to produce average monthly GVI values. Unsupervised classification (a statistical procedure without judgments introduced by the analyst) was performed on the 12 monthly layers to produce a 33-class map of landcover. Monthly GVI means and standard deviations for each class were extracted from the GIS and graphed. The resulting 'phenology curves' revealed the timing

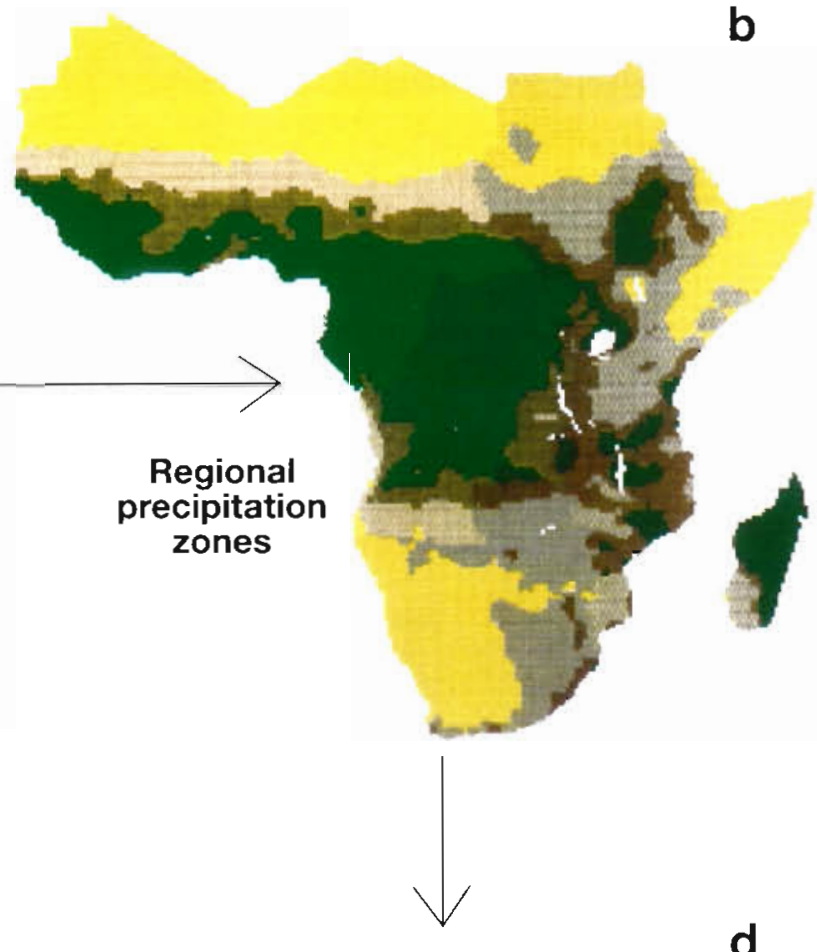



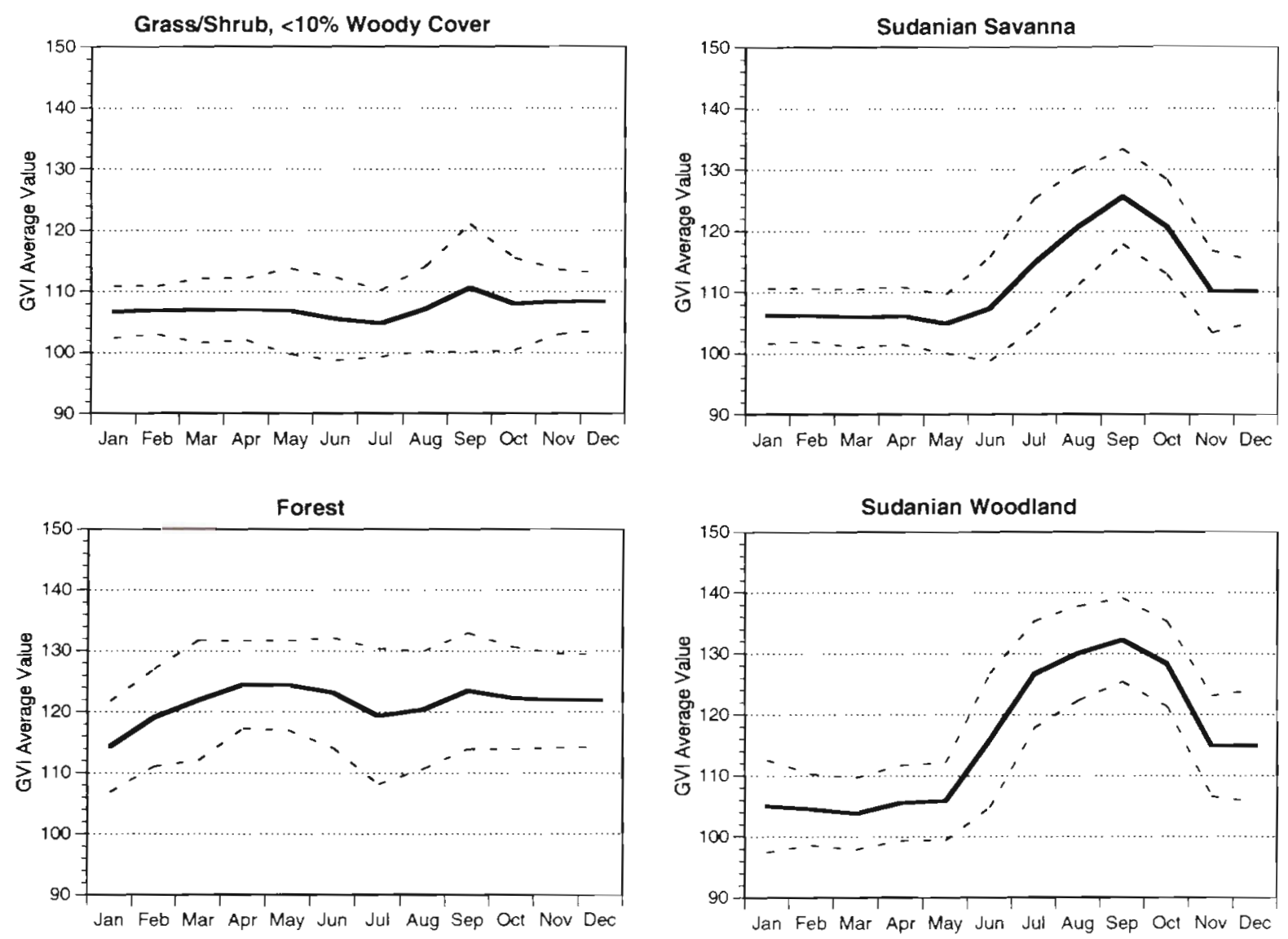

Fig. 3. Examples of seasonal variation in GVI (average \pm standard deviation) for different classes of land cover. NDVI is the difference between the reflected radiances measured in the near-infrared $\left(C_{\mathrm{NIR}}\right)(0.73$ to $1.1 \mu \mathrm{m})$ and visible $\left(C_{\text {VIs }}\right)(0.55$ to $0.68 \mu \mathrm{m})$ spectral regions (channels 1 and 2, respectively), divided by their sum:

$$
\text { NDVI }=\frac{C_{\mathrm{NIR}}-C_{\mathrm{VIS}}}{C_{\mathrm{NIR}}+C_{\mathrm{VIS}}}
$$

High values of GVI indicate that a greater proportion of the land is covered by photosythetically active vegetation

1993). First, the map was compared with White's (1983) map of vegetation for Africa. Estimates of the area in forest were 493 and $260 \times 10^{6}$ ha for White's map and ours, respectively. For woodlands, the areas were 798 and $881 \times 10^{6}$ ha, respectively. Unfortunately, the differences are not necessarily an assessment of accuracy. Rather, they represent changes in forest cover between an unspecified time in the past (White 1983) and the late 1980's (satellite-derived map). The loss of forests over time is consistent with this interpretation, and so is the increase in woodlands if some of today's woodlands are actually degraded forests.

For a better evaluation of accuracy, we asked what proportion of the areas (pixels) classified presently as forest were identified as forest in White's map. A pixelby-pixel comparison showed $95 \%$ agreement. Areas currently classified as woodlands were identified as woodlands with $85 \%$ frequency by White.
A second test for accuracy was a comparison of the GVI-based map and a map for South American land cover derived from $1 \mathrm{~km}$ AVHRR (Advanced Very High Resolution Radiometer) data (T. A. Stone unpubl.). The comparison showed $65 \%$ agreement overall, although any such comparison suffers from the different names given to classes of vegetation. Nevertheless, the 2 tests show that the GVI-based map compares reasonably well with other estimates of land cover in tropical regions.

Decision matrix. The intersection of the map of potential agroforestry (distribution of cases studies among the 16 regional precipitation zones; Fig. 2b) with the map of current land use (33 classes of landcover; Fig. 2c) determined the type of agroforestry appropriate at any location (Table 3). For example, timber agroforestry would be difficult to implement in arid and semi-arid pastoral areas; and the acacias that predominate in many pastoral agroforestry systems would 
Table 2. Land areas currently suitable for agroforestry, average biomass, and total aboveground biomass potentially stored in different types of agroforestry

\begin{tabular}{|c|c|c|c|c|c|c|c|}
\hline \multirow{2}{*}{$\begin{array}{l}\text { Agroforestry } \\
\text { type }\end{array}$} & \multirow{2}{*}{$\begin{array}{c}\text { Area } \\
\left(\times 10^{3} \text { ha }\right)\end{array}$} & \multicolumn{3}{|c|}{ Biomass $\left(t h a^{-1}\right)$} & \multicolumn{3}{|c|}{ Total biomass $\left(\times 10^{6} \mathrm{t}\right)$} \\
\hline & & $\begin{array}{l}\text { Low } \\
\text { estimate }\end{array}$ & $\begin{array}{l}\text { Medium } \\
\text { estimate }\end{array}$ & $\begin{array}{l}\text { High } \\
\text { estimate }\end{array}$ & $\begin{array}{l}\text { Low } \\
\text { estimate }\end{array}$ & $\begin{array}{l}\text { Medium } \\
\text { estimate }\end{array}$ & $\begin{array}{l}\text { High } \\
\text { estimate }\end{array}$ \\
\hline Pastoral $0-400 \mathrm{~mm}$ & 166463 & 0.18 & 0.36 & 0.72 & 30 & 60 & 120 \\
\hline Pastoral $400-800 \mathrm{~mm}$ & 178503 & 0.18 & 0.35 & 0.70 & 31 & 62 & 125 \\
\hline Pastoral > $800 \mathrm{~mm}$ & 112852 & 4.85 & 9.70 & 19.40 & 547 & 1095 & 2189 \\
\hline Fruit & 296788 & 3.00 & 7.50 & 15.00 & 890 & 2226 & 4452 \\
\hline Fuelwood & 74576 & 15.40 & 38.50 & 77.00 & 1148 & 2871 & 5742 \\
\hline Timber & 7537 & 130.00 & 240.00 & 270.00 & 980 & 1809 & 2035 \\
\hline Shelterbelt & 105 & 6.49 & 6.49 & 6.49 & 1 & 1 & 1 \\
\hline Pastoral/Fruit $0-400 \mathrm{~mm}$ & 0 & 1.59 & 3.93 & 7.86 & 0 & 0 & 0 \\
\hline Pastoral/Fruit $400-800 \mathrm{~mm}$ & 0 & 1.59 & 3.93 & 7.85 & 0 & 0 & 0 \\
\hline Pastoral/Fruit $>800 \mathrm{~mm}$ & 4494 & 3.93 & 8.60 & 17.20 & 18 & 39 & 77 \\
\hline Pastoral/Fuelwood 0-400 mm & 2255 & 7.79 & 19.43 & 38.86 & 18 & 44 & 88 \\
\hline Pastoral/Fuelwood $400-800 \mathrm{~mm}$ & 49689 & 7.79 & 19.43 & 38.85 & 387 & 965 & 1930 \\
\hline Pastoral/Fuelwood > $800 \mathrm{~mm}$ & 229900 & 10.13 & 24.10 & 48.20 & 2328 & 5541 & 11081 \\
\hline PastoraL/Shelterbelt $0-400 \mathrm{~mm}$ & 52525 & 3.34 & 3.43 & 3.61 & 175 & 180 & 189 \\
\hline Pastoral/Shelterbelt $400-800 \mathrm{~mm}$ & 16449 & 3.33 & 3.42 & 3.60 & 55 & 56 & 59 \\
\hline Pastoral/Shelterbelt $>800 \mathrm{~mm}$ & 17190 & 5.67 & 8.10 & 12.95 & 97 & 139 & 223 \\
\hline Fruit/Fuelwood & 258022 & 9.20 & 23.00 & 46.00 & 2374 & 5935 & 11869 \\
\hline Fruit/Timber & 30415 & 66.50 & 123.75 & 142.50 & 2023 & 3764 & 4334 \\
\hline Fruit/Shelterbelt & 26937 & 4.75 & 7.00 & 10.75 & 128 & 188 & 289 \\
\hline Fuelwood/Timber & 767 & 72.70 & 139.25 & 173.50 & 56 & 107 & 133 \\
\hline Fuelwood/Shelterbelt & 23407 & 10.95 & 22.50 & 41.75 & 256 & 527 & 977 \\
\hline Total: & 1548874 & & & & 11541 & 25607 & 45914 \\
\hline
\end{tabular}

be difficult to encourage in humid, forested areas where fruit tree or timber agroforestry would more closely complement current land use. Thus, when more than one type of agroforestry was possible, the type most similar to current land use was chosen. Combinations were also possible (Table 2). If a landcover/landuse labelled 'savanna with $>10 \%$ woody vegetation/grazed' intersected with fruit tree, shelterbelt, and silvopastoral agroforestry, then silvopastoral agroforestry was chosen. Some potential intersections between types did not occur, and some areas of landcover, such as dense tropical forest or extreme desert, were unsuited for the types of agroforestry considered in this study and were labelled as having no potential for agroforestry.

Decisions made concerning the intersection of potential types of agroforestry with current land use defined the types of agroforestry (Table 3 ) and the area with potential for application at present (Table 2). If more lands are deforested and degraded in the future, this potential will increase.

\section{RESULTS}

Table 1 summarizes the average tree weight, number of trees $\mathrm{ha}^{-1}$, and average aboveground biomass $h^{-1}$ for the different types of agroforestry found presently in sub-Saharan Africa. The average tree weights varied over 3 orders of magnitude, with very small trees $(3 \mathrm{~kg}$ ) in arid and semi-arid pastoral systems and very large trees $(3250 \mathrm{~kg})$ in agroforestry systems producing timber. The number of trees ha-1 varied as much within types of agroforestry as between them, with the exception of those systems with fuelwood. Fuelwood plantations generally contained the greatest number of (small) trees ha ${ }^{-1}$.

The average biomass ha-1 was largely a function of average tree weight, so that timber production had the largest potential to accumulate biomass, while arid and semi-arid silvopastoral systems had the smallest potential. Potential biomass accumulation in agroforestry systems increased in the following sequence: semi-arid silvopastoral, arid silvopastoral, shelterbelts, fruit tree, humid silvopastoral, fuelwood, and timber trees.

Table 2 shows the land area currently suitable for each agroforestry type (also shown in Fig. 2d), and the total amount of aboveground woody biomass that could be accumulated under each type. A total of 1549 $\times 10^{6}$ ha were estimated to be currently suitable for some form of agroforestry in sub-Saharan Africa. Six types of agroforestry accounted for more than $100 \times$ $10^{6}$ ha each. In descending order, these types were fruit tree, fruit tree/fuelwood, pastoral/fuelwood, and each of the 3 silvopastoral systems alone. Pastoral sys- 
Table 3. Decision matrix for determining appropriate agroforestry types at various locations: $1=$ Pastoral; $2=$ Fruit; $3=$ Fuelwood; $4=$ Timber; $5=$ Shelterbelt $;=$ Pastoral/Fruit $7=$ Pastoral/Fuelwood $;=$ Pastoral $/$ Shelterbelt; $9=$ Fruit $/$ Fuelwood; $10=$ Fruit $/$ Timber $11=$ Fruit/Shelterbelt $12=$ Fuelwood/Timber $; 13=$ Fuelwood/Shelterbelt. W: west ${ }_{i}$ C: central I $_{i}$ : east $t_{i}$ S: south

\begin{tabular}{|c|c|c|c|c|c|c|c|c|c|c|c|c|c|c|c|c|}
\hline \multirow{3}{*}{$\begin{array}{l}\text { Landcover } \\
\text { class name }\end{array}$} & \multicolumn{16}{|c|}{ Regional precipitation zone } \\
\hline & \multicolumn{4}{|c|}{ Arid } & \multicolumn{4}{|c|}{ Semi-arid } & \multicolumn{4}{|c|}{ Sub-humid } & \multicolumn{4}{|c|}{ Humid } \\
\hline & W & $\mathrm{C}$ & E & $S$ & W & C & $\mathrm{E}$ & $\mathrm{S}$ & W & $\mathrm{C}$ & $E$ & $\mathrm{~s}$ & W & C & $E$ & $\mathrm{~S}$ \\
\hline Desert & 0 & 0 & 0 & 0 & 0 & 0 & 0 & 0 & 0 & 0 & 0 & 0 & 0 & 0 & 0 & 0 \\
\hline Grass/Shrub, $<10 \%$ woody & 1 & 1 & 1 & 1 & 1 & 7 & 1 & 7 & 1 & 7 & 3 & 3 & 1 & 1 & 3 & 1 \\
\hline Sudan savanna & 1 & 0 & 1 & 7 & 7 & 0 & 1 & 1 & 1 & 0 & 3 & 3 & 1 & 0 & 3 & 0 \\
\hline Grassland/Sudanian woodland & 1 & 0 & 1 & 0 & 7 & 0 & 7 & 0 & 7 & 0 & 3 & 0 & 7 & 7 & 9 & 0 \\
\hline Salt desert & 0 & 0 & 0 & 0 & 0 & 0 & 0 & 0 & 0 & 0 & 0 & 0 & 0 & 0 & 0 & 0 \\
\hline Forest & 0 & 0 & 0 & 0 & 0 & 0 & 0 & 0 & 0 & 0 & 0 & 0 & 0 & 0 & 0 & 0 \\
\hline Edaphic grass/Semi-aquatic & 0 & 0 & 0 & 0 & 0 & 0 & 0 & 0 & 0 & 0 & 0 & 0 & 0 & 0 & 0 & 0 \\
\hline Pasture/Veld/Agricultural & 0 & 1 & 1 & 8 & 0 & 1. & 8 & 1 & 6 & 7 & 13 & 13 & 8 & 6 & 9 & 6 \\
\hline Sudanian woodland & 0 & 0 & 0 & 0 & 0 & 0 & 7 & 0 & 7 & 0 & 9 & 0 & 7 & 0 & 9 & 0 \\
\hline Shrubland/Bushland/Rainfed agric. & 0 & 0 & 1 & 0 & 11 & 9 & 9 & 9 & 9 & 9 & 13 & 13 & 11 & 9 & 9 & 9 \\
\hline Wooded/Bushed grassland & 0 & 0 & 0 & 0 & 0 & 7 & 3 & 7 & 0 & 7 & 3 & 3 & 7 & 7 & 3 & 7 \\
\hline Mosaic forest/Secondary grassland & 9 & 0 & 1 & 9 & 2 & 0 & 2 & 9 & 12 & 9 & 4 & 4 & 10 & 4 & 10 & 4 \\
\hline Moist miombo & 0 & 0 & 1 & 0 & 0 & 9 & 2 & 9 & 2 & 9 & 2 & 2 & 2 & 2 & 2 & 2 \\
\hline Miombo & 0 & 7 & 1 & 7 & 0 & 9 & 9 & 9 & 2 & 9 & 2 & 2 & 2 & 2 & 2 & 2 \\
\hline Dwarf/Sparse shrubland & 0 & 0 & 0 & 0 & 0 & 0 & 0 & 0 & 0 & 0 & 0 & 0 & 0 & 0 & 0 & 0 \\
\hline Plantation/Disturbed forest/Agric. & 9 & 0 & 0 & 0 & 2 & 0 & 2 & 0 & 0 & 2 & 10 & 10 & 10 & 10 & 10 & 10 \\
\hline Secondary/Degraded forest & 0 & 0 & 1 & 0 & 2 & 9 & 2 & 0 & 4 & 9 & 4 & 4 & 10 & 10 & 4 & 10 \\
\hline Montane vegetation & 0 & 0 & 0 & 0 & 0 & 0 & 0 & 0 & 0 & 0 & 0 & 0 & 0 & 0 & 0 & 0 \\
\hline Humid lowland tropical forest & 0 & 0 & 0 & 0 & 0 & 0 & 0 & 0 & 0 & 0 & 0 & 0 & 0 & 0 & 0 & 0 \\
\hline$>75 \%$ cultivated & 0 & 0 & 1 & 5 & 0 & 2 & 11 & 2 & 2 & 2 & 13 & 13 & 13 & 2 & 9 & 2 \\
\hline Fynbos shrubland & 1 & 0 & 1 & 1 & 1 & 0 & 1 & 7 & 7 & 0 & 3 & 3 & 7 & 1 & 3 & 1 \\
\hline Dune fynbos & 0 & 0 & 0 & 0 & 0 & 0 & 0 & 0 & 0 & 0 & 0 & 0 & 0 & 0 & 0 & 0 \\
\hline Proteoid fynbos & 0 & 0 & 0 & 1 & 0 & 7 & 1 & 7 & 0 & 7 & 3 & 3 & 7 & 1 & 3 & 1 \\
\hline Very moist miombo & 0 & 0 & 0 & 0 & 0 & 9 & 2 & 9 & 0 & 9 & 9 & 9 & 0 & 2 & 2 & 2 \\
\hline Shrubland/Mesotrophic fynbos & 0 & 0 & 1 & 0 & 1 & 0 & 0 & 7 & 0 & 7 & 3 & 3 & 7 & 1 & 0 & 0 \\
\hline $60-80 \%$ eroded/degraded & 0 & 0 & 1 & 0 & 0 & 0 & 3 & 0 & 0 & 0 & 13 & 0 & 0 & 0 & 3 & 0 \\
\hline $40-60 \%$ eroded $/$ degraded & 0 & 0 & 0 & 0 & 0 & 0 & 3 & 0 & 0 & 0 & 13 & 0 & 0 & 0 & 3 & 0 \\
\hline Cult. with some relicts mont forest & 0 & 0 & 0 & 0 & 0 & 0 & 9 & 0 & 0 & 0 & 11 & 0 & 0 & 0 & 2 & 0 \\
\hline Upland dry forest & 0 & 0 & 0 & 0 & 0 & 0 & 0 & 0 & 0 & 0 & 0 & 0 & 0 & 0 & 0 & 0 \\
\hline Lake/Aquatic vegetation & 0 & 0 & 0 & 0 & 0 & 0 & 0 & 0 & 0 & 0 & 0 & 0 & 0 & 0 & 0 & 0 \\
\hline Hi-elev. scattered Woodl./Forest & 0 & 0 & 0 & 0 & 0 & 0 & 9 & 0 & 0 & 0 & 3 & 0 & 0 & 0 & 2 & 0 \\
\hline Forest, various types & 0 & 0 & 0 & 0 & 0 & 0 & 0 & 0 & 0 & 0 & 0 & 0 & 0 & 0 & 0 & 0 \\
\hline Savanna/Wooded steppe/Rainf. ag. & 0 & 0 & 0 & 0 & 0 & 0 & 11 & 0 & 0 & 0 & 13 & 0 & 0 & 0 & 9 & 0 \\
\hline
\end{tabular}

tems, either alone or in combination with another type, accounted for a total of $830 \times 10^{6}$ ha. Systems with some amount of fuelwood accounted for $639 \times 10^{6}$ ha. And agroforestry where fruit trees were important for at least part of the practice accounted for $617 \times 10^{6} \mathrm{ha}$. The area suitable for agroforestry with timber was about $38 \times 10^{6}$ ha.

Applying the mean woody biomass in different agroforestry ecosystems (Table 1 ) to the areas suitable for each type gave total potential accumulations of aboveground biomass that were estimated to be 12,26 , or $46 \mathrm{Pg}$ depending on the density of tree planting.

Neither the land area occupied by each agroforestry type nor the average biomass $\mathrm{ha}^{-1}$ of each type predicted the system with the greatest potential to accumulate biomass. For example, timber agroforestry had the highest biomass ha ${ }^{-1}$ value, yet ranked seventh in total aboveground biomass. The largest area suitable for agroforestry was estimated to be that suited for fruit trees, but such systems ranked fifth in terms of biomass potentially accumulated. The type of agroforestry with the largest potential to accumulate biomass was the fruit/fuelwood agroforestry combination, which ranked second in land area. The agroforestry type estimated to accumulate the second largest amount of biomass (again using the high estimate) was the pastoral/fuelwood combination, which covered the third largest area.

The 5 agroforestry types with the greatest potential to accumulate biomass for the high estimate, were, in descending order: fruit/fuelwood; pastoral/fuelwood with $>800 \mathrm{~mm}$ precipitation; fuelwood; fruit/timber; and fruit. The 3 systems with the largest potential to accumulate biomass all included fuelwood. 


\section{DISCUSSION}

\section{Carbon storage estimates}

Converting now to units of carbon (carbon $=0.5 \times$ biomass), the potential accumulation of carbon in aboveground woody biomass was estimated to be 6 , 13, and $23 \mathrm{PgC}$ for the 3 tree densities. These estimates include only aboveground biomass. Assuming that belowground biomass accounts for about $20 \%$ of total biomass, total accumulation of carbon in above- and belowground woody biomass would range between 7 and $28 \mathrm{Pg} \mathrm{C}$. The estimates are lower than the value reported recently by Houghton et al. (1993). In that study, agroforestry in sub-Saharan Africa (on a total of $888 \times 10^{6}$ ha) was calculated to accumulate 52.6 Pg C in woody biomass, above- and belowground. The average accumulation per ha was $59 \mathrm{t} \mathrm{C} \mathrm{ha}^{-1}$ in that study, in comparison to 4.5 to $19 \mathrm{t} \mathrm{C} \mathrm{ha}^{-1}$ obtained here. The earlier estimate of carbon storage was based on the assumption that agroforestry systems accumulate about as much carbon ha ${ }^{-1}$ as held in natural woodlands. The results of the work described here suggest that this assumption is an overestimate.

Nevertheless, the estimates for carbon storage presented here, even accounting for belowground carbon accumulation, are probably underestimates. First, they are based only on woody biomass, and the practice of agroforestry is likely to accumulate additional carbon in soils. The potential of agroforestry to accumulate soil carbon is unknown, but can be approximated in 2 ways. First, if the accumulation in agroforestry is as great as the loss associated with cultivation of forest soils, the accumulation could be about $25 \%$ of the carbon content of the soils found in different ecosystems $\left(98,69\right.$, and $42 \mathrm{t} \mathrm{C} \mathrm{ha}^{-1}$, respectively, for tropical forests, woodlands, and grasslands) (Schlesinger 1984). The potential distribution of agroforestry among these ecosystems (Houghton et al. 1993) gives an average accumulation in soils of $26 \mathrm{Pg} \mathrm{C}$ for this region. It is important to recall that the value important here is the increment in soil carbon attributable to agroforestry, not the total amount of carbon in soil.

A second estimate may be based on the assumption that soils and biomass accumulate carbon in the same ratio that they lose carbon following deforestation. Soils account for between 15 and $20 \%$ of the net loss of carbon from changes in land use (Houghton 1991). According to this assumption, total accumulation of carbon in the soils of agroforestry systems of subSaharan Africa would be 1 to $6 \mathrm{Pg} \mathrm{C}$. Thus, total accumulation of carbon in agroforestry systems could be between 8 and $54 \mathrm{Pg}$ when soils, as well as belowground biomass, are considered.
It is clear that timber systems store almost an order of magnitude more carbon ha ${ }^{-1}$ than other systems and are the systems that should be promoted if carbon accumulation is to be maximized. This conclusion may be misleading, however. The area where timber complements existing land use is apparently small, and the strategy of replacing current land uses with timber plantations can be expected to meet considerable resistance from local land managers. Such a 'foreign' land use, imposed from 'outside', would have little success without significant changes in infrastructure, education, and technology. Rather than trying to promote the most carbon-intensive systems, a more appropriate strategy for storing carbon would be to complement inplace land uses. Under such a strategy, it is more likely that some form of carbon-storing system will be adopted. Strategies that consider the interplay of biomass $\mathrm{ha}^{-1}$ and land area will be more successful in determining the accumulation of carbon than biomass $\mathrm{ha}^{-1}$ alone. After all, the current trend in land use in the tropics is not reforestation but the loss of carbon through deforestation. The advantage of using agroforestry, rather than other types of reforestation, to accumulate carbon is that most deforestation takes place to increase the area in agriculture. To the extent that agroforestry is successful, it will tend to offset the carbon lost from deforestation. As discussed below, it may also help to reduce the extent of deforestation.

\section{Secondary effects of agroforestry on carbon storage}

Agroforestry also has secondary effects on carbon storage. It not only accumulates carbon on site but conserves carbon in existing forests by reducing the need for fuel and agricultural land normally obtained from neighboring forests. Two aspects of agroforestry are important in reducing losses of carbon from neighboring forests. First, agroforestry adds to the permanence of agriculture; second, it reduces the area required for agriculture.

Trees greatly enhance the agricultural permanence of a shifting agricultural production system. Because trees represent an investment over time, agroforestry serves as a disincentive to abandon agricultural lands. The additional food production and income generated by agroforestry trees reduces the reasons for abandoning land and moving on to cut new fields from forest. Trees also provide various service functions, such as increasing soil organic matter and nutrient levels and reducing runoff and soil loss, and these increase the productivity of fields beyond what occurs in fields without trees.

Trees included in agroforestry systems also reduce rates of deforestation. The supply of woody biomass for 
fuelwood within agroforestry can divert wood collection from forests and other natural stands, allowing these stands to maintain, and/or increase in, biomass. The effect of local fuel production is also beneficial to the farmer in time. In many parts of the developing world, households spend enormous amounts of time collecting fuelwood because of the distance between home and wood source. The time spent retrieving fuelwood reduces the time available for farming or other income-generating activities (Nair 1989c). Fuelwood trees in or around the farm allow more time for these activities (such as investment of time and assets in farming activities), increasing production and thereby adding to the permanence of agriculture. With agroforestry, lack of fuelwood ceases to be one of the reasons for moving on to a new location.

Agroforestry may also reduce the land required for self sufficiency. This reduction in required land area is due both to a greater physical output and to a greater concentration of agricultural capital and labor in the existing land area (Hoekstra 1990). The utilization of agroforestry trees has been observed to act as the glue that enables several different production systems or system components to take place on a single piece of land (Lundgren 1982, Winterbottom \& Hazelwood 1987). Interactions of livestock, fruit, timber, fuelwood, medicinal plant production, etc., can all take place on a single piece of land. Agroforestry does not always lead to an increase in agricultural productivity (Lal 1989), but when it does, the enhanced crop production further reduces the total land area needed to support a given population. And the greater income generated by many agroforestry designs means that less land may be needed for a given household to sustain itself (Hoekstra 1990). Thus, as long as the number of households remains constant, more land can remain in forest or is available for agroforestry.

This reduction in required land area, together with the increased agricultural permanence, may be more important in reducing emissions of carbon from deforestation than in accumulating carbon. In Africa, emis-

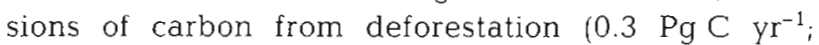
Houghton in press b) are 3 times higher than emissions from combustion of fossil fuels $(0.12 \mathrm{PgC}$ in 1985). Although most of the deforestation is for new agricultural lands, only $10 \%$ of the area deforested contributes to a net increase in agricultural area. Ninety percent of deforestation seems not to increase the area in agriculture but to replace worn out agricultural lands (Houghton in press a). If agricultural lands could be made sustainable, perhaps through agroforestry, rates of deforestation might be reduced by $90 \%$ without reducing the growth of productive agricultural areas. Emissions of biotic carbon would be reduced by $90 \%$, or by $0.27 \mathrm{Pg} \mathrm{C} \mathrm{yr}^{-1}$.
These secondary aspects of carbon storage due to agroforestry - greater agricultural permanence, and a reduction in land area - have been the focus of a great deal of agronomic research. Neither goal is easily attained. Attempts at creating greater agricultural permanence on less land in the tropics using techniques and technology (chemical, mechanical, institutional) imported from industrialized countries have not had a record of success. The simplistic view that the introduction of permanent agriculture will help address the large number of the interrelated environment-poverty problems of lesser developed nations ignores this record, the great deal of work that has been done on the topic, and the complexities of the human ecology issues involved.

In summary, there are 3 ways in which agroforestry acts to keep carbon out of the atmosphere: (1) through accumulation of carbon in woody biomass and soil, (2) through reduced deforestation of neighboring forests, and (3) through production of wood for fuel, as a substitute for fossil fuel. The first of these may lead to an accumulation of 8 to $54 \mathrm{Pg} \mathrm{C}$ in sub-Saharan Africa, but the accumulation continues only while the systems are developing. Eventually, agroforestry systems will reach a new equilibrium with respect to carbon, after which no further accumulation will occur.

The second way agroforestry keeps carbon out of the atmosphere, through reducing rates of deforestation, has the potential to continue indefinitely. If widespread implementation of agroforestry eliminated deforestation completely, emissions would be reduced by $0.3 \mathrm{Pg} \mathrm{C} \mathrm{yr}^{-1}$. After 25 to $180 \mathrm{yr}$, this secondary aspect of agroforestry would equal the primary effect of carbon storage. However, the major benefit of agroforestry, if it were to eliminate the need for additional agricultural land, would be the preservation of forests. African closed forests hold only about $30 \mathrm{PgC}$ in vegetation (Brown et al. 1989) and perhaps a similar amount in soils. At current rates of deforestation (FAO/UNEP 1981), these forests will be gone in less than $150 \mathrm{yr}$, releasing all of the carbon contained in vegetation and additional carbon from soils.

The third way agroforestry keeps carbon out of the atmosphere, by supplying wood fuels as a substitute for fossil fuels, is largely in effect in Africa, where up to $80 \%$ of energy use is from biomass. But in order for the substitution to work, the production of wood must be sustainable, and such is not the case at present. The argument advanced here is not that Africa continue to rely on wood as it has until now, but that new technologies based on wood fuels be developed so as to replace fossil fuels with efficient substitutes (Hall et al. 1991). The fact that fuelwood agroforestry systems are consistent with current land use in Africa is encouraging. 
Overall, the spread of agroforestry in Africa would offset global emissions of carbon from worldwide combustion of fossil fuels for only a few years at most. It could offset total African emissions from deforestation and fossil fuels for 20 to 125 yr. More importantly, the secondary effects of agroforestry in reducing deforestation might largely eliminate these emissions altogether. Thus, agroforestry could significantly affect the carbon balance for a large area of the world. Whether agroforestry can work in the long term, however, depends on the demands placed upon it by increases in the number of people seeking food and fuel and by changes in climate. Long-term persistence will require systems of land tenure consistent with the long-term nature of trees. It will require a stable number of farmers and a climate that is reasonably constant. Faced with growing numbers of refugees or with changes in precipitation or drought, the potential of agroforestry to accumulate carbon will be compromised.

Acknowledgements. Research supported by the U.S. Environmental Protection Agency under cooperative agreement CR818636

\section{LITERATURE CITED}

Anderson, D., Fishwick, R. (1984). Fuelwood consumption and deforestation in African countries. World Bank Staff Working Paper No. 704. World Bank, Washington, DC

Allen, J. A. (1990). Homestead tree planting in two rural Swazı communities. Agrofor. Syst. 11. 11-22

Almanza, S. G., Moya, E. G. (1986). The uses of Mesquite (Prosopis spp.) in the highlands of San Luis Potosi, Mexico. For. Ecol. Mgmt 16: 49-56

Barrow, E. G. C. (1991). Evaluating the effectiveness of participatory agroforestry extension programmes in a pastoral system, based on existing traditional values: a case study of the Turkana in Kenya. Agrofor. Syst. 14:1-21

Bille, J. C. (1985). Some aspects of bush encroachment in the African rangelands. In: Tothill, J. C., Mott, J. J. (eds.) Ecology and management of the world's savannas. International Savanna Symposium, Australian Academy of Science, Canberra, p. 213-216

Boudet, G. C., Toutain, B. (1980). The integration of browse plants within pastoral and agropastoral systems in Africa. In: Le Houerou, H. N. (ed.) Browse in Africa. Papers presented at the International Symposium on Browse in Africa, Addis Ababa, April 8-12. International Livestock Center for Africa, Addis Ababa, p. 427-432

Brown, S., Gillespie, A. J. R., Lugo, A. E. (1989). Biomass estimation methods for tropical forests with applications to forest inventory data. For. Sci. 35: 881-902

Brown, S., Lugo, A. E. (1984). Biomass of tropical forests: a new estimate based on volumes. Science 223: 1290-1293

Brown, S., Lugo,A. E., Chapman, J. (1986). Biomass of tropical tree plantations and its implications for the global carbon budget. Can. J. For. Res. 16: 390-394

Coppock, D. L., Ellis, J. E., Swift, D. M. (1986). Livestock feeding ecology and resource utilization in a nomadic pastoral ecosystem. J. appl. Ecol. 23: 573-583
Denevan, W. M., Padoch, C. (eds.) (1987). Swidden-fallow agroforestry in the Peruvian Amazon. Advances in economic botany, New York Botanical Garden, New York

FAO/UNEP (Food and Agriculture Organisation/United Nations Environmental Programme) (1981). Tropical Forest Resources Assessment Project. Forest Resources of Tropical America. FAO, Rome

Fernandes, E. C. M., O'Kting, A., Maghembe, J. (1984). The Chagga homegardens: a multistoryed agroforestry cropping on Mount Kilmanjaro (northern Tanzania). Agrofor. Syst. 2: 73-86

French, D. (1978). Firewood in Africa. Discussion Paper for the Africa Bureau Firewood Workshop. USAID, Washington, DC

Goward, S. N., Tucker, C. J., Dye, D. G. (1985). North American vegetation patterns observed with the NOAA-7 advanced very high resolution radiometer. Vegetatio 64 : $3-14$

Goward, S. N., Dye, D. G., Dulaney, W., Yang, J. (1990). Critical assessment of the NOAA Global Vegetation Index data product. Workshop on Use of Satellite-Derived Vegetation Indices in Weather and Climate Prediction Models. NOAA World Weather Building, Camp Springs, MD, U.S. Department of Commerce, National Oceanic and Atmospheric Administration, Washington, DC, p. $34-42$

Goward, S. N., Markham, B., Dye, D. G., Dulaney, W., Yang, $J$. (1991). Normalized difference vegetation index maeasurements from advanced very high resolution radiometer. Remote Sensing of Environment 35: 259-279

Goward, S. N., Dye, D. G., Turner, S., Yang, J. (in press). Objective assessment of the NOAA Global Vegetation Index data product. Int. J. Remote Sensing

Grainger, A. (1988). Estimating areas of degraded tropical lands requiring replenishment of forest cover. Int. Tree Crops J. 5: (1-2)

Hall, D. O., Mynick, H. E., Williams, R. H. (1991). Cooling the greenhouse with bioenergy. Nature 353: 11-12

Harrison, A. P. (1987). Trees for Africa. New Scient., May 14, $54-57$

Hoekstra D. A. (1990). Economics of agroforestry. In: MacDicken, K. G., Vergara, N. T. (eds.) Agroforestry: classification and management. John Wiley and Sons, New York, p. 310-331

Houghton, J. T., Callander, B. A., Varney, S. K. (1992). Climate change 1992. The Supplementary Report to the IPCC Scientific Assessment. Cambridge University Press, Cambridge

Houghton, J. T., Jenkins, G. T., Ephraums, J. J. (eds.) (1990). Climatic change. The IPCC Scientific Assessment. Cambridge University Press, Cambridge

Houghton, R. A. (1990). The future role of tropical forests in affecting the carbon dioxide concentration of the atmosphere. Ambio 19: 204-209

Houghton, R. A. (1991). Biomass burning from the perspective of the global carbon cycle. In: Levine, J. S. (ed.) Global biomass burning. MIT Press, Cambridge, MA, p. 321-325

Houghton, R. A. (in press a). The extent of land-use change, worldwide. BioScience

Houghton, R. A. (in press b). Tropical forests and climate. In: Primack, R. B., Lovejoy, T. E. (eds.) Ecology, conservation and management of the Southeast Asian Rainforests. Yale University Press, New Haven

Houghton, R. A., Unruh, J. D., Lefebvre, P. A. (1993). Current land use in the tropics and its potential for sequestering carbon. Global biogeochem. Cycles 7: 305-320 
Justice, C. O., Townshend, J. R. G., Holben, B. N. Tucker, C. J. (1985). Analysis of the phenology of global vegetation using meteorological satellite data. Int. J. Remote Sensing 6: 1271-1318

Lal, R. (1989). Potential of agroforestry as a sustainable alternative to shifting agriculture. Agrofor. Syst. 8: 239-242

Leach, G., Mearns, R. (1988). Beyond the fuelwood crisis. Earthscan Publications, London

Legates, D. R., Willmott, C. J. (1990). Mean seasonal and spatial variability in gauge-corrected global precipitation. Int. J. Climatol. 10: 111-127

Lundgren, B. (1982). What is agroforestry? Agrofor. Syst. 1: $7-12$

Maghembe, J. A., Kaoneka, A. R. S., Lulandala, L. L. L. (1986). Intercropping weeding and spacing effects on growth and nutrient content in Leucaena L. at Morogoro, Tanzania. For. Ecol. Mgmt 16: 296-279

Marland, G. (1988). The prospect of solving the $\mathrm{CO}_{2}$ problem through global reforestation. DOE/NBB-0082. U.S. Department of Energy. Washington, DC

Martin, S. C. (1985). Values and uses for Mesquite. In: Utilization of arid land plants: symposium proceedings, Saltillo, Mexico, Rocky Mountain Forest and Range Experiment Station. U.S. Department of Agriculture, Forest Service, Fort Collins, Report RM-135, p. 91-96

Michon, G., Mary, F., Bompard, J. (1986). Multistoryed home garden system in West Sumatra, Indonesia. Agrofor. Syst. 4: $315-338$

Millington, A., Townsend, J. (1989). Biomass assessment: woody biomass in the SADCC region. Earthscan Publications Ltd., London

Nair, P. K. R. (1985). Fruit trees in tropical agroforestry systems. Working Paper No. 32. International Council for Research in Agroforestry (ICRAF), Nairobi

Nair, P. K. R. (ed.) (1989a). Agroforestry systems in the tropics, Appendix I. Kluwer Academic Publishers and International Council for Research in Agroforestry, London

Nair, P. K. R. (1989b). Ecological spread of major agroforestry systems. In: Nair, P. K. R. (ed.) Agroforestry systems in the tropics. Kluwer Academic Publishers and International Council for Research in Agroforestry, London, p. 63-84

Nair, P. K. R. (1989c). Agroforestry and biomass energy/fuelwood production. In: Nair, P. K. R. (ed.) Agroforestry systems in the tropics. Kluwer Academic Publishers and
International Council for Research in Agroforestry, London, p. 591-597

Phillips, P., Munslow, B., O'Keefe, P. (1989). Sustainable solutions to land use conflicts: cattle and trees in the SADCC region. Land Use Policy 6: 151-161

Poschen, P. (1986). An evaluation of the Acacia albida-based agroforestry practices in the Hararghe highlands of eastern Ethiopia. Agrofor. Syst. 4: 129-143

Schlesinger, W. H. (1984). The world carbon pool in soil organic matter: a source of atmospheric $\mathrm{CO}_{2}$. In: Woodwell, G. M. (ed.) The role of terrestrial vegetation in the global carbon cycle: measurement by remote sensing. SCOPE 23. J Wiley and Sons, New York, p. 111-124

Sedjo, R. A. (1988). Forests: a tool to moderate global warming? Environment 31:14-20

Shankarnarayan, L. N., Harsh, L. N., Kathju, S. (1987). Agroforestry in the arid zones of India. Agrofor. Syst. 5: $69-88$

Toky, O. P., Kumar, P., Khosia, P. K. (1989). Structure and function of traditional agroforestry systems in the western Himalaya. I. Biomass and productivity. Agrofor. Syst. 9: $47-70$

Torres, F. (1983). Potential contribution of lencaena hedgerows intercropped with maize to the production of organic nitrogen and fuelwood in the lowland tropics. Agrofor. Syst. 1: 323-333

Torres, F. (1989). Tree-fodder and silvopastoral systems. In: Nair, P. K. R. (ed.) Agroforestry systems in the tropics. Kluwer Academic Publíshers and International Council for Research in Agroforestry, London, p. 553-566

Tucker, C. J., Townshend, J. R. G., Goff, T. E. (1985). African land-cover classification using satellite data. Science 227 : 369-375

Van Denbeldt, R. (1990). Agroforestry in the semiarid tropics. In: Macdicken, K. G., Vergara, N. T. (eds.) Agroforestry: classification and management. John Wiley and Sons, New York, p. 150-194

White, F. (1983). The vegetation of Africa. UNESCO/AETFAT/UNSO Vegetation Map of Africa. UNESCO, Paris

Winterbottom. R., Hazelwood, T. (1987). Agroforestry and sustainable development: making the connection. Ambio 16: $100-110$

Woodwell, G. M. (1989). The warming of the industrialized middle latitudes 1985-2050: causes and consequences. Clim. Change 15: $31-50$ 